\title{
Nutrition menu labelling in Terengganu: a cross-sectional study of knowledge, attitudes, perception and their relationship with healthy food choices
}

\author{
Marina, M., *Asma’ A., Jaafar, S.N.A., Abdul Wahab, M.R. and Wan Zainal Shukri, W.H. \\ Faculty of Fishery and Food Sciences, Universiti Malaysia Terengganu (UMT), 21030 Kuala Nerus, \\ Terengganu, Malaysia
}

\author{
Article history: \\ Received: 29 March 2020 \\ Received in revised form: 4 \\ May 2020 \\ Accepted: 15 May 2020 \\ Available Online: 30 May \\ 2020
}

\section{Keywords:}

Knowledge,

Attitude,

Perception,

Nutrition menu labelling,

Malaysia

\section{DOI:}

https://doi.org/10.26656/fr.2017.4(5).138

\begin{abstract}
Nutrition menu labelling has been implemented in a number of restaurants in Malaysia. However, no known empirical research has focused on assessing the knowledge, attitude and perception (KAP) of nutrition menu labelling among consumers. Therefore, this cross -sectional study was conducted with 155 consumers (age 18 and above) from several selected cafeterias that were equipped with menu nutrition labelling to determine their KAP. Questionnaires consisting of socio-demographic, knowledge, attitude and perception of consumers on menu nutrition labelling, and consumers' healthy food choices were given to the respondents through a self-administrated approach. The data collected were analysed using SPSS 21. The results show that respondent knowledge was predominantly moderate $(54.8 \%)$, with a median score of 12 out of 25 . Both the attitudes (87.1\%) and perceptions $(85.2 \%)$ of the respondents were mainly positive towards nutrition menu labelling. Attitude $(\mathrm{r}=0.547, \mathrm{p}=0.001)$ and perception $(\mathrm{r}=0.539, \mathrm{p}=0.001)$ had positive significant relationships towards healthy food choices among the respondents at $\mathrm{p}<0.05$. In conclusion, most consumers have a positive attitude and perception of nutrition menu labelling and may significantly influence towards healthy food choices. Further strategies are needed to increase consumer knowledge of nutrition menu labelling to promote greater usage of this information among Malaysian consumers.
\end{abstract}

\section{Introduction}

Recently in Malaysia, there has been increasing interest in the consumption of food away from home. Approximately 28,610 food services were available in Malaysia in 2009 (Ismawati et al., 2014). New fast food outlet also showed an upsurge of growth of up to $67 \%$ by 2004 to 2009 (Ismawati et al., 2014). However, this growth pattern has led to the increased prevalence of obesity and diet-related non-communicable disease. This has been an alarming concern to the Malaysia Ministry of Health $(\mathrm{MOH})$. Many approaches have been strategized by the $\mathrm{MOH}$, such as implementing and advocating the National Plan of Action for Nutrition III (2016 - 2025). One such initiative is the implementation of Bersih, Sihat, Selamat (BeSS) certificate for food premises in Malaysia. Its criteria include providing and promoting the correct portion sizes according to individual needs and nutrition labelling (MOH, 2016).

Recent evidence by Din et al. (2012) and Salhadi et al. (2018) suggests that providing nutrition menu labelling and calorie information helps consumers in making food choices and may ultimately lead to healthier selections. Nutrition menu labelling enforcement has been carried out in several countries. For example, in the United States chains with 20 or more establishments are required to provide nutritional information on menus (Lee-Kwan et al., 2016). In Canada, large chains are also required to provide nutritional information on their menus (White et al., 2016). In South Korea, nutritional information is required to be provided for children meals items (Ahn et al., 2015). As for Malaysia, the implementation has been gazetted on fast food outlets while for the other food services chain are voluntarily (MOH, 2016). Meanwhile, in Thailand (Ng et al., 2018) and many other Asian countries, implementation is still voluntary (Kasapila and Shaarani, 2011).

Knowledge and attitude play an important role in managing weight and partaking in healthy behaviour (Lee-Kwan et al., 2016); thus, knowledge and attitude related to nutrition menu labelling are prominent in encouraging healthier food choices for people (Roseman et al., 2013; Fakih et al., 2016; Radwan et al., 2017). Studies have also revealed that more menu information 
leads to healthier food consumption (Fakih et al., 2016). Nonetheless, few studies have been done gauging knowledge, attitude and perception of nutrition menu labelling among consumers, particularly in Terengganu. Thus, this study aims to assess the interrelationships among knowledge, attitude and perception of nutrition menu labelling and its association towards healthy food choices among consumers.

\section{Materials and methods}

\subsection{Research design}

This cross-sectional study was conducted at University Malaysia Terengganu (UMT), located in Kuala Nerus, Terengganu. The chosen cafeterias were Cafeteria Kolej Syed Abdul Malik (KKSAM) and Cafeteria Kolej Abdul Rahman Limbong (KKARL), which were selected through purposive sampling. The inclusion criterion for the study location was that the café must have provided nutrition menu labelling by displaying the calorie values of at least five menu items. The sample size of this study was calculated using the Cochrane formula (1977) at 95\% confident interval and $45 \%$ expected proportion with a $6 \%$ desired level of precision. To avoid a low response rate, the percentage of sample size was increased to $15 \%$. Therefore, a total of 155 respondents were recruited. Eligibility criteria required individuals to be a consumer at any of the selected café's, aged 18 and above, and willing to participate in this study. Inform consent was obtained prior to data collection. Data collection was conducted between July and September 2019. Ethical approval was obtained from the Human Ethics Board of Committees of Universiti Malaysia Terengganu with reference number JKEPM/2019/35.

\subsection{Research instrument}

The instrument used for this research was a selfadministrated questionnaire consist of five focal sections: socio-demographic, knowledge on nutrition menu labelling (NML), attitude on NML, perception of NML, and healthy food choices. The validity and reliability of the questionnaire were determined using internal validity and Cronbach's Alpha ( $>0.6$ to be reliable), correspondingly.

\subsection{Sociodemographic and general food label}

This section included eight items: gender, age, education level, occupation and also general food labelling questions (adopted from Malaysian Adults Nutrition Survey, Institute of Public Health, 2014).

\subsection{Knowledge on nutrition menu labelling}

The knowledge section consisted of 25 items concerning consumer general nutrition knowledge (18items) and nutrition menu labelling knowledge by comparing the calories of foods (7-items). Twenty-four were positive statements and one was negative statement (item 25). The answers provided were 'Yes', 'No' or 'Not Sure'. This questionnaire was self-constructed by referring to Malaysia Dietary Guideline (National Coordinating Committee on Food and Nutrition Ministry of Health Malaysia, 2013) taken from Key Message 1 'Eat variety of food within your calorie recommended intake' and also Panduan Penyajian Hidangan Sihat Semasa Mesyuarat (KKM, 2011). One point was given for the correct answer and zero points were given to the answer that is incorrect and not sure answer. The knowledge score range between 0 and 25 and were categorized as poor $(0-7$ points $)$, moderate $(8-14$ points) and high (15 - 25 points), respectively (Herath et al., 2017).

\subsection{Attitude on nutrition menu labelling}

Consumer attitudes on nutrition menu labelling consisted of 11 items. These items were derived from previous studies and modified to suit this study (Piron et al., 2010; Lassen et al., 2014; Parikh and Behnke, 2015; Kim and Ham, 2017). The responses for this section were along a five-point Likert Scale. The scores for the positive questionnaire were as follows: 5-strongly agree, 4-agree, 3-neutral, 2-disagree, and 1-strongly disagree, while for the negative questions were scored on the reverse. The score ranges from 11 to 55 and higher score indicated a higher level of attitude or positive attitudes. Score 35 and above considered as positive attitude (Jeruszka-Bielak et al., 2018).

\subsection{Perception of nutrition menu labelling}

Consumer perception of nutrition menu labelling included 9 items adopted from previous study conducted by Din et al. (2012). The responses for this section were along a five-point Likert Scale as follows: 5-strongly agree, 4-agree, 3-neutral, 2- disagree, and 1-strongly disagree. Scores ranging from 9 to 45 and higher indicated higher level of perception or positive perception. Scores of 22 and above were considered as positive perception (Norazlanshah et al., 2013).

\subsection{Healthy food choices among consumer}

This last part comprise of 10 items self-developed questionnaire and was adopted from a previous study by Bauer and Reisch (2018). The responses for this section were along a five-point Likert Scale as follows: 5strongly agree, 4-agree, 3-neutral, 2-disagree, and 1strongly disagree. Score ranging from 10 to 50 and higher indicated a higher level of healthy food choices or 
good healthy food choices. Score 25 and above considered as good healthy food choices.

\subsection{Data analysis}

Data were analysed using IBM SPSS version 21. Normality tests were performed prior to data analysis. Since the data were not normally distributed, continuous data has been presented in the form of median and interquartile range. Spearman tests were performed to determine the correlations between knowledge, attitude, perception and healthy food choices with a significance level of $\mathrm{p}<0.05$.

\section{Results and discussion}

\subsection{Socio-demographic characteristic of respondents}

Table 1 indicates that most of the respondents were female students between 18 and 24 years old. As shown in Table 1, three general questions were asked concerning the nutrition labels. For "Do you read the nutrition labelling when you buy or receive food (where applicable)?" the percentage obtained for 'yes, always' was $16.1 \%$; 'yes, sometimes' $76.8 \%$; and 'no' $7.1 \%$. Based on Institute of Public Health (2014), 45\% of respondents read the food label. It has been reported that those who usually read food labels are female, had a tertiary academic level and were not single (Ambak et al., 2018). For the understanding of food label; approximately $16.8 \%$ always understand; $72.9 \%$ sometimes understand; and $10.3 \%$ do not understand food labels. Ambak et al. (2018) stated that many consumers fail to understand food labels due to a low academic level. For the present study, a possible explanation for this might lay in difficulty reading the small-print food labels and also a lack of nutrition education. In terms of what information was read from the menu labels, most respondents read the information on total energy at $70.3 \%$, followed by carbohydrates including sugar at $48.4 \%$ and food additives at $45.8 \%$. In Ambak et al.'s (2018) study, respondents paid more attention to reading the expiry dates and precautionary statements only, while only $14.4 \%$ read total energy, with $21.5 \%$ reading sugar information and $19.9 \%$ reading fat information.

\subsection{Knowledge on nutrition menu labelling}

Table 2 shows the distribution of knowledge based on the correctly answered items. What stands out in the table is only two items concerning consumer general nutrition knowledge, namely items 1 and 12 , received the most correct answers. This result was as expected, as item 1 , which is the definition of a calorie, and item 12 , which refers to the suggested servings of fruit per day, are common knowledge. This is because this information
Table 1. Sociodemographic and consumer food label information $(n=155)$.

\begin{tabular}{|c|c|}
\hline Sociodemographic Profile & Frequency $(\%)$ \\
\hline \multicolumn{2}{|l|}{ Age } \\
\hline 18-24 years old & $133(85.8)$ \\
\hline 25-34 years old & $11(7.1)$ \\
\hline $35-44$ years old & $2(1.3)$ \\
\hline 45-54 years old & $4(2.6)$ \\
\hline$\geq 55$ years old & $5(3.2)$ \\
\hline \multicolumn{2}{|l|}{ Gender } \\
\hline Male & $64(41.3)$ \\
\hline Female & $91(58.7)$ \\
\hline \multicolumn{2}{|l|}{ Race } \\
\hline Malay & $136(87.7)$ \\
\hline Chinese & $11(7.1)$ \\
\hline Indian & $6(3.9)$ \\
\hline Others & $2(1.3)$ \\
\hline \multicolumn{2}{|l|}{ Level of Education } \\
\hline SPM and equivalent level & $23(14.8)$ \\
\hline Currently doing Diploma/Asasi & $39(25.2)$ \\
\hline Currently doing Degree & $91(61.3)$ \\
\hline Currently doing Master/PhD & $2(1.3)$ \\
\hline \multicolumn{2}{|l|}{ Occupation } \\
\hline Student & $120(77.4)$ \\
\hline Staff & $35(22.6)$ \\
\hline \multicolumn{2}{|c|}{$\begin{array}{l}\text { Do you read the nutrition labelling when you } \\
\text { buy or receive food (where applicable)? }\end{array}$} \\
\hline Yes, always & $25(16.1)$ \\
\hline Yes, sometimes & $119(76.8)$ \\
\hline No & $11(7.1)$ \\
\hline \multicolumn{2}{|l|}{$\begin{array}{l}\text { a What kind of information in the nutrition } \\
\text { label do you read? }\end{array}$} \\
\hline Total energy & $109(70.3)$ \\
\hline Carbohydrate content including sugar & $75(48.4)$ \\
\hline Salt/Sodium content & $41(26.5)$ \\
\hline Vitamin Content & $37(23.9)$ \\
\hline Mineral Content & $17(11.0)$ \\
\hline Food additives & $71(45.8)$ \\
\hline Fibre & $20(12.9)$ \\
\hline \multicolumn{2}{|c|}{$\begin{array}{l}\text { Do you understand the information in the food } \\
\text { label when you buy or receive food? }\end{array}$} \\
\hline Yes, always & $26(16.8)$ \\
\hline Yes, sometimes & $113(72.9)$ \\
\hline No & $16(10.3)$ \\
\hline
\end{tabular}

${ }^{\mathrm{a}}$ can choose more than one answer

has been well-advertised on mass media and social network. This is supported by a study conducted by Pon et al. (2006) which found that nutritional knowledge among the public is mostly obtained from newspaper and magazines.

It is apparent from Table 2 that most of the respondents could give correct answers for the calorie comparison of a given meal, except for items 24 and 25 . This was quite surprising because it indicates that consumers appeared to have the knowledge of the nutrition menu label. However, this result contradicts those of a study conducted by Zainordin et al. (2015) 
Table 2. Distribution of respondent responses to nutritional menu labelling knowledge $(n=155)$

\begin{tabular}{|c|c|c|c|c|}
\hline \multirow[t]{2}{*}{ Items } & Yes & No & Not Sure & $\begin{array}{l}\text { Answered } \\
\text { Correctly }\end{array}$ \\
\hline & $\mathrm{n}(\%)$ & $\mathrm{n}(\%)$ & $\mathrm{n}(\%)$ & $\mathrm{n}(\%)$ \\
\hline 1. Calorie is a measure of the energy in food. & $128(82.6)$ & $6(3.9)$ & $21(13.5)$ & $128(82.6)$ \\
\hline 2. The calorie required for sedentary women is $1500 \mathrm{kcal}$. & $43(27.7)$ & $11(7.1)$ & $101(65.2)$ & $43(27.7)$ \\
\hline 3. The calorie required for active women is $2000 \mathrm{kcal}$. & $56(36.1)$ & $13(8.4)$ & $86(55.5)$ & $56(36.1)$ \\
\hline 4. The calorie required for active men is $2500 \mathrm{kcal}$. & $77(49.7)$ & $8(5.2)$ & $70(45.2)$ & $77(49.7)$ \\
\hline 5. Fat contributes the highest calorie of $9 \mathrm{kcal}$ per 1 gram. & $62(40.0)$ & $20(12.9)$ & $73(47.1)$ & $62(40.0)$ \\
\hline 6. Protein provides $4 \mathrm{kcal}$ per gram of food. & $62(40.0)$ & $9(5.8)$ & $84(54.2)$ & $62(40.0)$ \\
\hline 7. Carbohydrate contributes 4 kcal per gram of food. & $57(36.8)$ & $11(7.1)$ & $87(56.1)$ & $57(36.8)$ \\
\hline $\begin{array}{l}\text { 8. One plate of fried rice contains a higher calorie content than one plate of } \\
\text { white rice. }\end{array}$ & $126(81.3)$ & $14(9.0)$ & $15(9.7)$ & $126(81.3)$ \\
\hline 9. The recommended daily intake of sugar is 50 grams. & $45(29.0)$ & $30(19.4)$ & $80(51.6)$ & $45(29.0)$ \\
\hline 10. The higher the fat content in the food, the higher the calorie content. & $110(71.0)$ & $29(18.7)$ & $16(10.3)$ & $110(71.0)$ \\
\hline 11. The recommended serving size for cereal and grains is $4-8$ servings per day & $35(22.6)$ & $42(27.1)$ & $78(50.3)$ & $35(22.6)$ \\
\hline $\begin{array}{l}\text { 12. The recommended serving size for fruits and vegetables is } 2-3 \text { servings per } \\
\text { day. }\end{array}$ & $110(71.0)$ & $12(7.7)$ & $33(21.3)$ & $110(71.0)$ \\
\hline 13. The recommended serving size for protein is $1 / 2$ to 1 serving per day. & $68(43.9)$ & $33(21.3)$ & $54(34.8)$ & $68(43.9)$ \\
\hline $\begin{array}{l}\text { 14. The recommended serving size for nuts and dairy products is } 1 / 2-2 \text { servings } \\
\text { per day. }\end{array}$ & $61(39.4)$ & $22(14.2)$ & $72(46.5)$ & $61(39.4)$ \\
\hline 15. 'Teh peng' contains higher calories than 'teh o'. & $132(85.2)$ & $11(7.1)$ & $12(7.7)$ & $132(85.2)$ \\
\hline 16. The calorie for one plate of white rice is about $240 \mathrm{kcal}$. & $50(32.3)$ & $14(9.0)$ & $91(58.7)$ & $50(32.3)$ \\
\hline 17. 'Roti bakar' spread with jam contains higher calories than plain 'roti bakar'. & $126(81.3)$ & $15(9.7)$ & $14(9.0)$ & $126(81.3)$ \\
\hline 18. The recommended calorie intake for breakfast is approximately $400 \mathrm{kcal}$. & $52(33.5)$ & $18(11.6)$ & $85(54.8)$ & $52(33.5)$ \\
\hline 19. The recommended calorie intake for morning tea is approximately $250 \mathrm{kcal}$. & $42(27.1)$ & $20(12.9)$ & $93(60)$ & $42(27.1)$ \\
\hline 20. The recommended calorie intake for lunch is approximately $500 \mathrm{kcal}$. & $49(31.6)$ & $27(17.4)$ & $79(51.0)$ & $49(31.6)$ \\
\hline 21. The recommended calorie intake for teatime is approximately $250 \mathrm{kcal}$. & $47(30.3)$ & $18(11.6)$ & $90(58.1)$ & $47(30.3)$ \\
\hline 22. The recommended calorie intake for dinner is approximately $400 \mathrm{kcal}$. & $38(24.5)$ & $28(18.1)$ & $89(57.4)$ & $38(24.5)$ \\
\hline 23. 'Limau ice' contains a lower calorie content than 'sirap limau.' & $101(65.2)$ & $25(16.1)$ & $29(18.7)$ & $101(65.2)$ \\
\hline 24. Fried chicken contains a higher calorie content than chicken curry. & $51(32.9)$ & $74(47.7)$ & $30(19.4)$ & $51(32.9)$ \\
\hline 25. 'Fried mee' has a lower calorie content than 'mee sup.' & $82(52.9)$ & $49(31.6)$ & $24(15.5)$ & $49(31.6)$ \\
\hline
\end{tabular}

Table 3. Attitude on nutrition menu labelling among respondents $(\mathrm{n}=155)$

\begin{tabular}{|c|c|c|c|c|c|c|}
\hline \multirow[t]{2}{*}{ Items } & $\begin{array}{l}\text { Strongly } \\
\text { Disagree }\end{array}$ & Disagree & Unsure & Agree & $\begin{array}{l}\text { Strongly } \\
\text { Agree }\end{array}$ & \multirow{2}{*}{$\begin{array}{l}\text { Median } \\
\text { (IQR) }\end{array}$} \\
\hline & $\mathrm{n}(\%)$ & $\mathrm{n}(\%)$ & $\mathrm{n}(\%)$ & $\mathrm{n}(\%)$ & $\mathrm{n}(\%)$ & \\
\hline 1. I found nutrition menu label helpful. & $2(1.3)$ & $5(3.2)$ & $9(5.8)$ & $71(45.8)$ & $68(43.9)$ & $4(1)$ \\
\hline 2. I appreciate having nutrition menu label at the café I ate. & $3(1.9)$ & $3(1.9)$ & $9(5.8)$ & $69(44.5)$ & $71(45.8)$ & $4(1)$ \\
\hline 3. It is interesting for me to read the nutrition menu label. & $3(1.9)$ & $5(3.2)$ & $27(17.4)$ & $78(50.3)$ & $42(27.1)$ & $4(1)$ \\
\hline $\begin{array}{l}\text { 4. It is worth reading the nutrition menu label before buying } \\
\text { any food. }\end{array}$ & $3(1.9)$ & $8(5.2)$ & $18(11.6)$ & $69(44.5)$ & $57(36.8)$ & $4(1)$ \\
\hline $\begin{array}{l}\text { 5. I would use calorie information to order low-calorie foods } \\
\text { and drinks. }\end{array}$ & $6(3.9)$ & $19(12.3)$ & $40(25.8)$ & $62(40.0)$ & $28(18.1)$ & $4(1)$ \\
\hline 6. It is beneficial for me to read the nutrition menu label. & $3(1.9)$ & $3(1.9)$ & $25(16.1)$ & $58(37.4)$ & $66(42.6)$ & $4(1)$ \\
\hline $\begin{array}{l}\text { 7. I trust the nutritional information provided on the nutrition } \\
\text { menu label. }\end{array}$ & $4(2.6)$ & $19(12.3)$ & $34(21.9)$ & $63(40.6)$ & $35(22.6)$ & $4(1)$ \\
\hline $\begin{array}{l}\text { 8. The nutritional information provided affects my decision to } \\
\text { purchase. }\end{array}$ & $5(3.2)$ & $19(12.3)$ & $40(25.8)$ & $70(45.2)$ & $21(13.5)$ & $4(1)$ \\
\hline 9. I prefer to eat in a restaurant with a menu label. & $5(3.2)$ & $19(12.3)$ & $34(21.9)$ & $63(40.6)$ & $34(21.9)$ & $4(1)$ \\
\hline 10. I am satisfied with the provided menu label. & $3(1.9)$ & $7(4.5)$ & $36(23.2)$ & $70(45.2)$ & $39(25.2)$ & $4(1)$ \\
\hline 11. I always read the menu label. & $7(4.5)$ & $28(18.1)$ & $46(29.7)$ & $54(34.8)$ & $20(12.9)$ & $3(1)$ \\
\hline
\end{tabular}


which found that calorie knowledge among students in Universiti Malaysia was low. This may be due to a lack of exposure to calorie information in their surroundings, particularly at the students' cafeterias.

\subsection{Attitude on restaurant's menu label}

Table 3 shows the degree of consumer agreement in terms of their attitudes towards nutrition menu labels. The table indicates that consumers in this study had positive attitudes towards nutrition menu labelling. Surprisingly, item 1 stated that $43.9 \%$ of the consumer in UMT cafes strongly agree and $45.8 \%$ agree that nutrition menu label is useful for them. Similarly, item 2 had $45.8 \%$ of the consumer strongly agree that they appreciate having menu labels at the cafes. Although the implementation of nutrition menu labels in Malaysia is not yet as compulsory and influential as nutrition food label, consumers generally find them to be useful. This finding is consistent with those of Radwan et al. (2017), who found that $47 \%$ of the participant reported that nutrition menu labels are useful, especially among female consumers.

\subsection{Perception of restaurant menu labelling}

For Table 4, the most surprising aspect is that consumers predominantly had good expectations for nutrition menu labels. This result is similar to those of previous studies which showed that consumers tend to use nutrition menu labels when provided and that nutrition menu labels are helpful if provided (Fernandes et al., 2015). A study by Parikh and Behnke (2015) showed that nutritional information influences the decision-making process. However, some consumers who do not make their food selections based on the nutritional information have still indicated that they found the information valuable and appreciate its availability. The findings on consumer perceptions of nutrition menu labelling may reflect their expectations of the nutrition menu labelling provided at cafeterias. Therefore, health authorities should enhance and promote the nutrition menu information provided in the cafeterias and food premises to aid consumers in making healthy food choices, since their perception of nutrition menu label is already at a good level.

\subsection{Healthy food choices among café consumers}

Table 5 indicates that most of the respondents made healthy food choices, as almost all of them tended to eat food that offers lower fat and lower salt. They also chose foods that are healthier rather than those offering sensory appeal, convenience, prices, and familiarity. 23.9\% strongly agreed and $49 \%$ agreed that they chose healthier food to control their weight. This result is supported by a study done by Ambak et al. (2014), which showed that those who desire to lose weight will tend to prefer healthier food and refer to nutrition labels.

Unexpectedly, fewer than $50 \%$ of consumers strongly agreed and agreed that they refer to the menu label to estimate their calorie consumption. These results are likely to be related to their preference on other dietary suggestion (i.e. sugar intake, fat intake, etc.), or perhaps they take no precautions in terms of their daily energy intake. These results indicate that awareness among consumers of menu labelling is still low.

\subsection{Overall knowledge, attitude and perception score distributions}

All in all, the respondents have moderate knowledge, positive attitude and perception of nutrition menu labelling as shown in Table 6. This finding showed that respondents managed to have a good attitude and

Table 4. Perception of nutrition menu labelling among respondents $(\mathrm{n}=155)$

\begin{tabular}{|c|c|c|c|c|c|c|}
\hline \multirow[t]{2}{*}{ Items } & $\begin{array}{l}\text { Strongly } \\
\text { Disagree }\end{array}$ & Disagree & Unsure & Agree & $\begin{array}{l}\text { Strongly } \\
\text { Agree }\end{array}$ & \multirow{2}{*}{$\begin{array}{l}\text { Median } \\
\text { (IQR) }\end{array}$} \\
\hline & $\mathrm{n}(\%)$ & $\mathrm{n}(\%)$ & $\mathrm{n}(\%)$ & $\mathrm{n}(\%)$ & $\mathrm{n}(\%)$ & \\
\hline 1. Nutritional information on the menu is important to me. & $3(1.9)$ & $7(4.5)$ & $22(14.2)$ & $75(48.4)$ & $49(31.0)$ & $4(1)$ \\
\hline $\begin{array}{l}\text { 2. I believe that nutritional information helps me to determine } \\
\text { the nutrition intake when I dine in a restaurant. }\end{array}$ & $4(2.6)$ & $14(9.0)$ & $22(14.2)$ & $80(51.6)$ & $35(22.6)$ & $4(1)$ \\
\hline $\begin{array}{l}\text { 3. I am interested in finding nutritional information of the } \\
\text { menu items in a restaurant. }\end{array}$ & $5(3.2)$ & $14(9.0)$ & $50(32.3)$ & $64(41.3)$ & $22(14.2)$ & $4(1)$ \\
\hline $\begin{array}{l}\text { 4. I intent to pay attention to nutritional information while } \\
\text { choosing a menu item in a restaurant. }\end{array}$ & $4(2.6)$ & $21(13.5)$ & $45(29.0)$ & $63(40.6)$ & $22(14.2)$ & $4(1)$ \\
\hline 5. I am confident that I will use nutritional information. & $11(7.1)$ & $26(16.8)$ & $50(32.3)$ & $61(39.4)$ & $7(4.5)$ & $3(1)$ \\
\hline $\begin{array}{l}\text { 6. I would like to see additional nutritional information about } \\
\text { menu items in a restaurant. }\end{array}$ & $8(5.2)$ & $17(11.0)$ & $45(29.0)$ & $69(44.5)$ & $16(10.3)$ & $4(1)$ \\
\hline $\begin{array}{l}\text { 7. Restaurant should provide nutrition information in the } \\
\text { menu. }\end{array}$ & $4(2.6)$ & $6(3.9)$ & $22(14.2)$ & $82(52.9)$ & $41(26.5)$ & $4(1)$ \\
\hline $\begin{array}{l}\text { 8. I believe nutritional information should not be misleading. } \\
\text { 9. Nutritional information (carbohydrate, protein, fat) }\end{array}$ & $3(1.9)$ & $10(6.5)$ & $20(12.9)$ & $63(40.6)$ & $59(38.1)$ & $4(1)$ \\
\hline $\begin{array}{l}\text { indicated by percentage is sufficient for me to know how } \\
\text { many ingredients the food contains. }\end{array}$ & $6(3.9)$ & $14(9.0)$ & $46(29.7)$ & $65(41.9)$ & $24(15.5)$ & $4(1)$ \\
\hline
\end{tabular}


Table 5. Distribution of healthy level food choices among respondents $(n=155)$

\begin{tabular}{|c|c|c|c|c|c|c|}
\hline \multirow[t]{2}{*}{ Items } & $\begin{array}{l}\text { Strongly } \\
\text { Disagree }\end{array}$ & Disagree & Unsure & Agree & $\begin{array}{l}\text { Strongly } \\
\text { Agree }\end{array}$ & \multirow{2}{*}{$\begin{array}{l}\text { Median } \\
\text { (IQR) }\end{array}$} \\
\hline & $\mathrm{n}(\%)$ & $\mathrm{n}(\%)$ & $\mathrm{n}(\%)$ & $\mathrm{n}(\%)$ & $\mathrm{n}(\%)$ & \\
\hline 1. I would buy food that is low in fat. & $0(0)$ & $4(2.6)$ & $25(16.1)$ & $75(48.4)$ & $51(32.9)$ & $4(1)$ \\
\hline 2. I would buy food that is in low salt. & $1(0.6)$ & $3(1.9)$ & $23(14.8)$ & $76(49.0)$ & $52(33.5)$ & $4(1)$ \\
\hline $\begin{array}{l}\text { 3. I would buy food that provides nutritional information on } \\
\text { the menu. }\end{array}$ & $0(0)$ & $6(3.9)$ & $19(12.3)$ & $80(51.6)$ & $30(32.3)$ & $4(1)$ \\
\hline $\begin{array}{l}\text { 4. I will compare the label before choosing the most nutritious } \\
\text { food. }\end{array}$ & $1(0.6)$ & $17(11.0)$ & $46(29.7)$ & $60(38.7)$ & $31(20.0)$ & $4(1)$ \\
\hline $\begin{array}{l}\text { 5. I will calculate the consumption of my calorie intake by } \\
\text { referring to the menu label. }\end{array}$ & $3(1.9)$ & $17(11.0)$ & $60(38.7)$ & $60(38.7)$ & $15(9.7)$ & $3(1)$ \\
\hline $\begin{array}{l}\text { 6. I'm going to choose food that is healthier than sensory } \\
\text { appeal. }\end{array}$ & $1(0.6)$ & $21(13.5)$ & $40(25.8)$ & $62(40.0)$ & $31(20.0)$ & $4(1)$ \\
\hline 7. I'm going to choose food that is healthier than convenience. & $3(1.9)$ & $25(16.1)$ & $43(27.7)$ & $59(38.1)$ & $25(16.1)$ & $4(1)$ \\
\hline 8. I'm going to choose food that is healthier than the price. & $1(0.6)$ & $23(14.8)$ & $48(31.0)$ & $56(36.1)$ & $27(17.4)$ & $4(1)$ \\
\hline $\begin{array}{l}\text { 9. I'm going to choose food that is healthier than the } \\
\text { familiarity of food. }\end{array}$ & $1(0.6)$ & $17(11.0)$ & $40(25.8)$ & $78(50.3)$ & $19(12.3)$ & $4(1)$ \\
\hline $\begin{array}{l}\text { 10. I'm going to choose food that is healthier for weight } \\
\text { control. }\end{array}$ & $4(2.6)$ & $15(9.7)$ & $23(14.8)$ & $76(49.0)$ & $37(23.9)$ & $4(1)$ \\
\hline
\end{tabular}

positive perception even though the implementation of the nutrition menu label is still novice as stated by Din et al. (2012). Din et al. (2012) stated that the consumer in full-services restaurants does support the use of the nutrition menu label. In agreement with the present results, a previous study by Kim et al. (2013) demonstrated that consumers in Hong Kong restaurants had a good attitude towards the implementation of menu labels in restaurants. However, more nutrition education programs need to be developed to ensure that consumers are able to understand those nutrition menu labels with a positive attitude.

Table 6. Overall Knowledge, Attitude and Perception score distributions $(\mathrm{n}=155)$

\begin{tabular}{lcc}
\hline \multirow{2}{*}{ Components } & \multicolumn{2}{c}{ Distributions } \\
\cline { 2 - 3 } & $\mathrm{n}(\%)$ & Score median (IQR) \\
\hline Knowledge & $30(19.4)$ & \\
$\quad$ Poor $(0-7)$ & $85(54.8)$ & $12(6)$ \\
Moderate $(8-14)$ & \\
High $(15-25)$ & $40(25.8)$ & \\
Attitude & & \\
$\quad$ Negative $(<35)$ & $20(12.9)$ & \\
Positive $(>35)$ & $135(87.1)$ & $46(8)$ \\
Perception & & \\
Negative $(<22)$ & $6(3.9)$ & \\
Positive $(>22)$ & $149(96.1)$ & \\
Healthy Food Choices & & \\
$\quad$ Poor $(<25)$ & $8(5.2)$ & \\
Good $(>25)$ & $147(94.8)$ & \\
\hline
\end{tabular}

Knowledge score $(\min =0, \max =25)$, Attitude score $(\min =11$, $\max =55)$, Perception score $(\min =9, \max =45)$, Healthy food choices score $(\min =10, \max =50)$

3.7 Relationship between knowledge, attitude and perception with healthy food choices level among selected cafe's consumer

The most obvious finding to emerge from this correlation coefficient analysis is that there is a significant positive relationship between attitude, perception and healthy food choices at $\mathrm{p}<0.05$, with the notable absence of knowledge as shown in Table 7 . Interestingly, knowledge showed a non-significant correlation with healthy food choices. These findings broadly support the work of Delvarani et al. (2013) which found that proposed nutritional knowledge is not the main predicator of intention to use the nutrition menu label. This outcome is contrary to those of studies which link nutritional knowledge with nutrition label usage. Zainol et al. (2018) stated that knowledge significantly and positively influences attitude towards organic food, implying the positive effect of knowledge on attitude. It is perhaps surprising that there was a moderate positive relationship between attitude and healthy food choices. Acheampong and Haldeman (2013) explained that consumers with higher nutrition knowledge are more likely to have positive attitudes about healthy eating. However, a recent study by Mogre et al. (2017) found that consumers' nutrition related knowledge does not correlate with their attitudes, and thus will not affect nutritional label usage. Lastly, based on the present study it can be concluded that both the attitudes and perceptions of consumers play an important role in choosing healthier food, even though the implementation of nutritional labels is rather new in Malaysia compared to other countries like the US. Thus, more educational health-related interventions need to be conducted to

Table 7. Relationship between knowledge, attitude and perception with healthy food choices level $(n=155)$

\begin{tabular}{lcc}
\hline & \multicolumn{2}{c}{ Healthy Food Choices } \\
\cline { 2 - 3 } & r-value & p-value \\
\hline Knowledge & 0.036 & 0.65 \\
Attitude & 0.547 & $0.001^{*}$ \\
Perception & 0.539 & $0.001^{*}$ \\
\hline
\end{tabular}

* Significant at $\mathrm{p}<0.05$

C 2020 The Authors. Published by Rynnye Lyan Resources 
educate and promote nutritional labels.

\section{Conclusion}

This cross-sectional study aimed to determine levels of knowledge, attitude and perception towards nutrition menu labelling and its relationship towards healthy food choices among selected café's consumer. Findings showed that most of the café's consumer showed moderate nutrition knowledge but positive attitude and perception of nutrition menu labelling, and a good level of healthy food choices. This study produced results which corroborate the findings of a great deal of the previous work there is a significant correlation between attitude, perception and healthy food choices at $\mathrm{p}<0.05$.

Despite its exploratory nature, this study has provided a deeper insight into knowledge, attitude and perception towards nutrition menu labelling and healthy food choices among the consumer in Terengganu. The empirical findings in this study may be of broad use to the health-related authorities to implement more programs to promote consumer on using nutrition menu labelling in their daily life.

\section{Conflict of interest}

The authors declare no conflict of interest.

\section{Acknowledgements}

The authors thank all the respondents for their participation, full cooperation, and patience in completing the study. This study was funded under the Universiti Malaysia Terengganu (UMT)'s Knowledge and Technology Assimilation Grant (KTAG 2018) scheme.

\section{References}

Acheampong, I. and Haldeman, L. (2013). Are nutrition knowledge, attitudes, and beliefs associated with obesity among low-income Hispanic and African American women caretakers? Journal of Obesity, 2013, 123901. https://doi.org/10.1155/2013/123901

Ahn, J.Y., Park, H.R., Lee, K., Kwon, S., Kim, S., Yang, J. and Lee, Y. (2015). The effect of providing nutritional information about fast-food restaurant menus on parents' meal choices for their children. Nutrition Research and Practice, 9(6), 667-672. https://doi.org/10.4162/nrp.2015.9.6.667

Ambak, R., Naidu, B.M., Omar, M.A., Azian, N., Zaki, M. and Mohd, S. (2014). Food Label Reading and Understanding among Obese Adults: A Population Study in Malaysia. International Journal of Public Health Research, 4(2), 449-456.
Bauer, J.M. and Reisch, L.A. (2018). Behavioural Insights and (Un)healthy Dietary Choices: a Review of Current Evidence. Journal of Consumer Policy, 42, 3-45. https://doi.org/10.1007/s10603-018-9387-y

Delvarani, S., Ghazali, H. and Othman, M. (2013). Factors affecting fast food consumers' intention to use menu labeling in Klang Valley, Malaysia. International Food Research Journal, 20(4), 17991805 .

Din, N., Zahari, M.S.M. and Shariff, S.M. (2012). Customer Perception of Nutritional Information in Restaurant Menu. Procedia - Social and Behavioral Sciences, 42, 413-421. https://doi.org/10.1016/ j.sbspro.2012.04.205

Fakih, K., Assaker, G., Assaf, A.G. and Hallak, R. (2016). Does restaurant menu information affect customer attitudes and behavioral intentions? A cross-segment empirical analysis using PLS-SEM. International Journal of Hospitality Management, 57, 71-83. https://doi.org/10.1016/ j.ijhm.2016.06.002

Fernandes, A.C., Oliveira, R.C., Rodrigues, V M., Fiates, G.M.R. and Proença, R.P. (2015). Perceptions of university students regarding calories, food healthiness, and the importance of calorie information in menu labelling. Appetite, 91, 173178. https://doi.org/10.1016/j.appet.2015.04.042

Herath, H.M.M., Weerasinghe, N.P., Dias, H. and Weerarathna, T.P. (2017). Knowledge, attitude and practice related to diabetes mellitus among the general public in Galle district in Southern Sri Lanka: a pilot study. BMC Public Health, 17(1), 1-7. https://doi.org/10.1186/s12889-017-4459-5

Ismawati, S., Mohamed, Z. and Rezai, G. (2014). Healthy Eating: The Preventive Factors among Malaysians. Journal of Economics, Business and Management, 2(4), 257-261. https://doi.org/10.7763/ JOEBM.2014.V2.135

Jeruszka-Bielak, M., Kollajtis-Dolowy, A., Santoro, A., Ostan, R., Berendsen, A.A.M., Jennings, A., Meunier, N., Marseglia, A., Caumon, E., Gillings, R., de Groot, L.C.P.G. M., Franceschi, C., Hieke, S. and Pietruszka, B. (2018). Are Nutrition-Related Knowledge and Attitudes Reflected in Lifestyle and Health Among Elderly People? A Study Across Five European Countries. Frontiers in Physiology, 9, 994. https://doi.org/10.3389/fphys.2018.00994

Kasapila, W. and Shaarani, S.M.D. (2011). Harmonisation of food labelling regulations in southeast asia: Benefits, challenges and implications. Asia Pacific Journal of Clinical Nutrition, 20(1), 18. https://doi.org/10.6133/apjen.2011.20.1.01 
Kim, E. and Ham, S. (2017). Development and validation of a measure of consumer behaviors toward nutritional labeling in restaurants. Journal of Foodservice Business Research, 20(5), 595-610. https://doi.org/10.1080/15378020.2016.1229440

Kim, E., Ham, S., Yang, I.S. and Choi, J.G. (2013). The roles of attitude, subjective norm, and perceived behavioral control in the formation of consumers' behavioral intentions to read menu labels in the restaurant industry. International Journal of Hospitality Management, 35, 203-213. https:// doi.org/10.1016/j.ijhm.2013.06.008

KKM (Kementerian Kesihatan Malaysia). (2011). Panduan Penyajian Hidangan Sihat Semasa Mesyuarat. $2^{\text {nd }}$ ed., p. 1-38. Retrieved from KKM website: https://docs.jpa.gov.my/docs/se/2012/ panduan.pdf

Lassen, A.D., Beck, A., Leedo, E., Andersen, E.W., Christensen, T., Mejborn, H., Thorsen, A.V. and Tetens, I. (2014). Effectiveness of offering healthy labelled meals in improving the nutritional quality of lunch meals eaten in a worksite canteen. Appetite, 75, 128-134. https://doi.org/10.1016/ j.appet.2013.12.005

Lee-Kwan, S.H., Pan, L., Maynard, L.M., McGuire, L.C. and Park, S. (2016). Factors Associated with SelfReported Menu-Labeling Usage among US Adults. Journal of the Academy of Nutrition and Dietetics, 116(7), 1127-1135. https://doi.org/10.1016/ j.jand.2015.12.015

Institute for Public Health. (2014). National Health and Morbidity Survey 2014: Malaysian Adult Nutrition Survey (MANS). Volume III: Food Consumption Statistics of Malaysia. Malaysia: Institute for Public Health, Ministry of Health Malaysia. Retrieved from Institute for Public Health, Ministry of Health Malaysia website: http://iku.moh.gov.my/images/ IKU/Document/REPORT/NHMS2014-MANSVOLUME-3-

FoodConsumptionStatisticsofMalaysia.pdf

National Coordinating Committee on Food and Nutrition Ministry of Health Malaysia. (2013). Malaysian Dietary Guidelines for Children and Adolescents. Malaysia: Technical Working Group on Nutritional Guidelines, Ministry of Health, Malaysia. Retrieved from Nutrition Division, Ministry of Health website: http://nutrition.moh.gov.my/wp-content/uploads/ penerbitan/buku/

MDG_Children_adolescent_2014.pdf

Mogre, V., Aryee, P.A., Stevens, F.C. and Scherpbier, A.J.A. (2017). Future Doctors' Nutrition-Related Knowledge, Attitudes and Self-Efficacy Regarding Nutrition Care in the General Practice Setting: A
Cross-Sectional Survey. Medical Science Educator, 27(3), 1-8. doi:10.1007/s40670-017-0413-5

$\mathrm{MOH}$ (Ministry of Health). (2016). Keselamatan, Program Kualiti, dan Pemakanan, Bahagian BERSIH, SELAMAT DAN SIHAT (BeSS) BAGI PREMIS. Retrieved from Bahagian Pemakanan Kementerian Kesihatan Malaysia website: http:// nutrition.moh.gov.my/bersih-selamat-dan-sihat-bess/

Ng, S., Swinburn, B., Kelly, B., Vandevijvere, S., Yeatman, H., Ismail, M.N. and Karupaiah, T. (2018). Extent of implementation of food environment policies by the Malaysian Government: Gaps and priority recommendations. Public Health Nutrition, 21(18), 3395-3406. https://doi.org/10.1017/ S1368980018002379

Norazlanshah, H., Muhammad, I., Hasmira, M.D., Mashita, M., Norfazlila, M.R. and Fazlyla, N.M.F. (2013). The Use of Nutrition Label on Food Purchasing Decision among University Students in Kuantan, Malaysia. Health and the Environmental Journal, 4(1), 1-10.

Parikh, A.A. and Behnke, C. (2015). Nutrition Label Formatting: Customer Perceptions and Behaviors. Journal of Foodservice Business Research, 18(1), 48 -57. https://doi.org/10.1080/15378020.2015.995751

Piron, J., Smith, L.V., Simon, P., Cummings, P.L. and Kuo, T. (2010). Knowledge, attitudes and potential response to menu labelling in an urban public health clinic population. Public Health Nutrition, 13(4), $550-555$. https://doi.org/10.1017/ S1368980009991303

Pon, L.W., Noor-Aini, M.Y., Ong, F.B., Adeeb, N., Seri, S.S., Shamsuddin, K., Mohamed, A.L., Hapizah, N., Mokhtar, A. and Wan, H.W.H. (2006). Diet, nutritional knowledge and health status of urban middle-aged Malaysian women. Asia Pacific Journal of Clinical Nutrition, 15(3), 388-399.

Radwan, H., Faroukh, E.M. and Obaid, R.S. (2017). Menu labeling implementation in dine-in restaurants: The Public's knowledge, attitude and practices. Archives of Public Health, 75, 8. https:// doi.org/10.1186/s13690-017-0177-9

Roseman, M.G., Mathe-Soulek, K. and Higgins, J.A. (2013). Relationships among grocery nutrition label users and consumers' attitudes and behavior toward restaurant menu labeling. Appetite, 71, 274-278. doi: 10.1016/j.appet.2013.08.019.

Salhadi, N.A., Ab Hamid, M.R., Osman, N.S. and Md Nor, N. (2018). Practice and Challenges towards Healthy Cafeteria in Selangor, Malaysia. Asian Journal of Quality of Life, 3(12), 127. https:// doi.org/10.21834/ajqol.v3i12.149 
White, C.M., Lillico, H.G., Vanderlee, L. and Hammond, D. (2016). A voluntary nutrition labeling program in restaurants: Consumer awareness, use of nutrition information, and food selection. Preventive Medicine Reports, 4, 474-480. https://doi.org/10.1016/ j.pmedr.2016.08.015

Zainordin, N.H., Budiningsari, D., Jalambo, M., Wali, H., Sivaji, A., Choon, O.T., Haruna E., Suresh, M. and Omar, B. (2015). Knowledge level of calories and BMI of the students of the National University of Malaysia. Pakistan Journal of Nutrition, 14(12), 931-937. https://doi.org/10.3923/pjn.2015.931.937 